\title{
低騒音ヘリコプタ・ブレードの開発とその実証について*1 Design and Evaluation of a Low-Noise Helicopter Blade
}

\author{
近 藤 夏 樹*2 过 内 智 郁*3 ·村 重 敦*3 - 西 村 宏 貴*3 - 青 木 誠*3 \\ Natsuki Kondo, Tomoka Tsujiuchi, Atsushi Murashige, Hiroki Nishimura, Makoto Aoki, \\ 土 橋 明 彦*3 $\cdot 山 川$ 榮 $-{ }^{* 4} \cdot$ 青 山 剛 史 ${ }^{* 5} \cdot$ 齊 藤 茂*5 \\ Akihiko Tsuchinashi, Eiichi Yamakawa, Takashi Aoyama and Shigeru Saito
}

Key Words : Helicopters, Tip Shape, Noise, Stall

\begin{abstract}
A low-noise helicopter blade, AT1, was designed with the concept of reducing noise without the drop of rotor performance. In the concept, High-Speed Impulsive (HSI) noise is reduced by applying a thin airfoil in the tip region and a dog-tooth like extension in the leading-edge of the tip region. Blade-Vortex Interaction (BVI) noise is reduced by applying the extension and a strong taper near the tip end. The stall angle of the blade is increased by the effect of the vortex generated from the leading-edge extension. As a result, the drop of rotor performance caused by the thin airfoil and the reduction of rotor rotational speed is recovered. The low-noise characteristics and the performance of AT1 were evaluated by a model rotor test conducted at Deutsch Niederländischer Windkanal (DNW). It is shown that AT1 reduces HSI noise and BVI noise and has good performance in forward flight conditions. However, the improvement of performance in high-lift conditions still remains as a future problem.
\end{abstract}

記 号 の 説 明

$C \quad$ : 翼弦長

$C_{1} \quad: 2$ 次元揚力係数

$C_{1 \max }$ : 最大 2 次元揚力係数

$C_{\mathrm{D}}: 3$ 次元抵抗係数

$C_{\mathrm{L}}: 3$ 次元揚力係数

$C_{\mathrm{L} \text { max }}$ : 最大 3 次元揚力係数

$C_{\mathrm{M}}: 3$ 次元モーメント係数

$C_{\mathrm{T}}$ : ロータ推力係数

$M \quad$ : マッ八数

$M_{\mathrm{dd}} \quad$ : 抵抗発散マッハ数

$M_{\mathrm{TIP}}$ ：ブレード翼端マッハ数

$\mathrm{OA} \quad$ : オーバー・オール音圧レベル

$R$ : ロータ回転半径

$\mathrm{SPL} ：$ 音圧レベル

$t / C:$ 翼厚比

$V \quad$ : 前進速度

$\alpha \quad$ : 迎角

$\alpha_{\mathrm{TPP}}$ : ロータ・チップ・パス・プレーン傾角

$\theta_{\mathrm{t}} \quad:$ ブレード局所ピッチ角

$\psi$ : ロータ方位角

$\mu$ : ロー夕前進率

\footnotetext{
*1 C) 2003 日本航空宇宙学会

平成 14 年 3 月 29 日原稿受理

*2 日本飛行機 (株)

*3 川崎重工業 (株)

*4 元 (株) コミュータヘリコプタ先進技術研究所

$* 5$ 航空宇宙技術研究所
}

1.は じめ に

最近，ドクター・ヘリに代表されるようにへリコプタは 救急医療や災害救助など, 樣々な分野での活躍が期待され るようになってきた．しかし，都市部やへリポート周辺の 住宅街からはへリコプタ騒音に対する苦情が多く，飛行経 路や運航時間帯が制限を受けたり，新しいヘリポートの設 置が妨げられるといった問題がヘリコプタの活躍の場を狭 めている．現在運用中のヘリコプタについては, 飛行経路 を変えることで少しでも地上への騷音を減らす等の対策が とられているが, 将来に新しく開発されるへリコプタに対 しては, 設計段階から低騒音を考慮することが求められる． 一般的にヘリコプタの機外騒音は，騒音を耳にする人間 が機体から遠方にいると考えるならば，弚の大半がロータ から発生する空力騒音で, 中でも特に支配的と言われるの が高速衝撃 (High Speed Impulsive: HSI) 騷音およびブ レード/渦干渉 (Blade Vortex Interaction: BVI) 騷音と 呼ばれる 2 種類の衝撃騒音である. HSI 騒音はへリコプタ が高速巡航時, 前進側ブレードの翼面上に局所的な超音速 領域が生まれることで発生する衝撃波に起因する騒音であ る.一方，BVI騷音はブレードが自身または他のブレード が放出する翼端渦と干渉することによって生ずる翼端前縁 付近の圧力の急変動に起因する衝撃騒音で, 低速降下時や マヌーバ時に発生しやすい. 最近のロータ騒音低減の研究 は，ほとんどがこの 2 種類の騒音低減をターゲットにして いると言ってよい

基本的なロータ騷音の低減方法としては, ブレード枚数 の増加, 回転数の低減, 翼端部の薄翼化などの方法が一般 
的によく言われるが1)，ロータ騒音の発生源が主に翼端付 近であることに着目すると, 翼断面を含む翼端部形状の改 良も騒音低減に高い効果が期待できる. 产のため, 翼端形 状の改良による騒音低減効果については数多くの研究が報 告されている21. これらの欧米の研究軌跡をたどると，当 初は飛行性能の向上を目的とした翼端形状の研究が中心で あったのが，近年になって徐々に騒音低減に主眼が置かれ るようになってきていることがわかる . 第 1 图に欧米で研 究されてきた翼端形状の例として著名なものを 4 つ示す. これらの 4 つ翼端形状はいずれも実験を中心に研究され たものである.第 1 図上段の Parabolic 翼3) およびBERP 翼は元々ヘリコプタの高速化を実現するために考案された が，最近になって騒音低減にも効果があると報告されてい る翼端形状で, 下段の VANE 翼および OGEE 翼は最初か ら騒音低減を目標とし, 主にBVI騷音の低減を狙って研究 されてきた形状である . 以下に各形状の騒音低減効果を簡 単に解説する。

Parabolic 翼は高速巡航時にロータ前進側で起こる衝撃 波の問題を改善するため, フランスの ONERA が研究を進 めてきた翼端形状である . 曲線状の前縁は衝撃波を効果的 に抑制する効果があり，当然のことながら衝撃波に起因し て発生する HSI 騒音も低減されるが, 近年の実験結果から はBVI騒音の低減にも効果があることか報告されている ${ }^{4)}$. Parabolic 翼は現在ではユーロコプター社の主要な機体や BK117-C2 で実用化されている .

$\mathrm{BERP}^{5)}$ はイギリスの Westland 社が立ち上げた先進 ブレードの研究プロジェクトの総称であるが, 光こから 生まれた前縁部が張り出したへら型の翼端形状のことを 一般に BERP 翼と呼んでいる. BERP 翼のコンセプトは Parabolic 翼と異なり，高速巡航時にロータ後退側で起こ る翼端失速抑制とモーメント特性の改善を狙っている．原 理的には Dog-tooth と呼ばれる前縁の張り出し部分から発 生する渦の誘導速度を利用し，高迎角時の剝離を防いで失 速を遅らせるというものである. 騒音低減への効果につい ては, 実験デー夕等は公開されていないが, 解析的研究で は衝撃波か漒いスパン位置で翼弦長を広げることで衝撃波 強度を弱めるため，HSI 騷音の低減に効果があると報告さ れている6).

VANE 翼7) は BERP 翼と同じく Westland 社が研究を
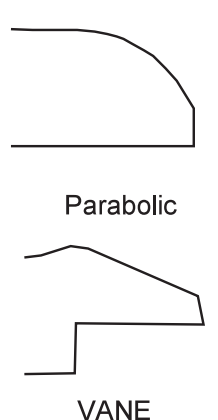

VANE

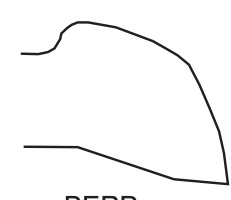

BERP

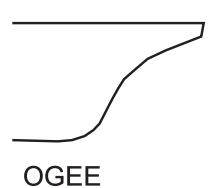

第1図欧米諸国の先進翼端形状の事例
進めてきた形状で，後縁に大きな切り欠きがあるのが特徵 的である.この形状は翼端部と切り欠き部から 2 本の渦を 発生させ，これらが互いに相殺することで凧を弱めて BVI 発生時の圧力変動を小さくし, 騒音を低減するというコン セプトである、ただし, 解析による比較では荷重変動が矩形 よりも小さくなることが報告されているが, 実験データ等 の報告はなく，現時点では実用化の予定はないようである

OGEE 翼はNASA がBVI騒音を低減する翼端形状とし て研究を進めてきたもので, 実験機により, 弚の効果を実 証している8). OGEE 翼は後縁がなだらかに前進している ため, コア半径の大きな弱い渦が発生することが 3 次元翼 模型を使った風洞試験で確認されている ${ }^{9)}$.

このような背景のもと, 基盤技術研究促進センター (通産 省/郵政省関連の特殊認可法人) からの出資を仰ぎ , 川崎重 工業 (株), (株) 島津製作所, 東京航空計器 (株), 帝人製機 (株)，日本飛行機 (株) の民間 5 社の参加の下，平成 6 年 3 月 に (株) コミュータヘリコプタ先進技術研究所 (Advanced Technology Institute of Commuter-helicopter: ATIC) か設立され，将来へリコプタの基盤技術としてヘリコプタ の機外騷音低減および飛行安全性の研究を 7 年間に渡り実 施してきた ${ }^{10)}$. 研究は平成 13 年 3 月をもって終了し, 機外 騒音低減の研究の最終的な成果として, 回転半径 $2 \mathrm{~m}$ のモ デル・ロータを用いた風洞試験結果と解析による予測結果 から，ロータ性能は現用機並に維持しつつ, ICAO 基準よ り機外騒音を $10 \mathrm{EPNdB}$ 下げられる技術の見通しを得た . 上記のヘリコプタ機外騒音低減の研究は, 特にメイン・ ロータの低騒音化に主眼をおいて進められた . 乥の基本コン セプトは可変回転数機構を有する 5 枚ブレード・ロータに， 新しい翼型/翼端形状を組み合わせた先進ブレードを適用し たものである.さらにHHC (Higher Harmonic Control) やアクティブ・フラップといったブレードのアクティブ・コ ントロールによる騒音低減についても基礎研究を実施して きた .ただし，アクティブ・ブレード・コントロール技術は 実用化に時間とコストがかかることら, 翼端形状の改良 といったパッシブ・デザインによる騒音低減の研究が先行 して行われてきた . 具体的には航空宇宙技術研究所との共 同研究によって翼端形状の違いか騒音に与える影響につい て樣々な解析を実施し, 独自に風洞試験によるデータの蓄 積を行いながら，新しいブレードの研究を進めてきた。乥 の研究の集大成として, 第 2 图に示す AT1 と呼ばれる新 型ブレードを設計してモデル・ロータに適用し，世界最大

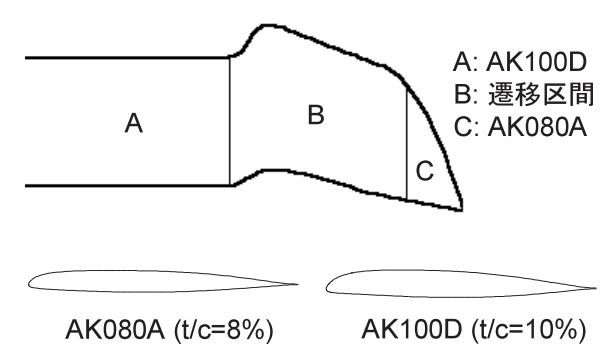

第 2 図 AT1 翼端の外形 
の低騒音風洞であるオランダの DNW (Deutsch Niederländischer Windkanal) において, ロータ性能およひ騒音 を確認するための試験を実施した，本論文では，AT1 ブ レードの開発とモデル・ロータ風洞試験による実証結果に ついて報告する．

\section{2. $\mathrm{AT} 1$ ブレードの設計指針}

新ブレードの設計に当たっては，ロータ騷音低減を目標 とするのはもちろんであるが，実用化に不向きとならない よう，低騒音化したことによってロータ性能が著しく低下 することのないよう考慮した . 特に低騒音へリコプタの構 想では, ロータ回転数をなるべく低くして飛行することを 想定しているため, 新ブレードには回転数を低くしても飛 行性能を維持できるように性能を向上させることが求めら れた、騒音低減の設計指針としては，先に述べた 2 種類の 衝撃騒音，即ち HSI 騒音と BVI 騒音の低減に主眼を置き， 性能面では薄翼化や回転数低下に伴って問題となるロータ 後退側の翼端失速抑制を目標とした。 .乥こで, 翼端部が高 迎角まで失速せず，かつ衝撃騒音の低減にも効果が高いと 予測される BERP 形状 (第 1 图参照) をべースとし, 騒音 や性能への影響を並行して確認しながら細部の形状を決め ていく手順をとった .

BERP 翼は端部で翼面積が大きく，ピッチリンク荷重増 大といったデメリットが予想されたため，性能や騒音への 影響が小さいと思われる後縁形状を変え, 前縁張り出しの ある区間で後縁を前進させることで面積を矩形とほぼ同じ となるようにした . 騒音については CFD を中心とした解 析により検討し, 失速特性については固定翼模型による低 速風洞試験により検討した。前縁形状が失速特性や衝撃騒 音に与える影響を調べたところ, 失速特性の方か騒音に比 へて前縁形状の違いに対する感度が高かったため, 風洞試 験で失速特性が最も良かった形状から各部の詳細な寸法を 決めていった .

翼型は薄翼化かつ高性能化を目標に, 翼端部用に厚み比 $8 \%$ ，翼根部用に厚み比 $10 \%$ の翼型を乥れぞれ設計した。. 翼 端部に適用する翼型は高速巡航時の性能を考え，抵抗発散 マッ八数 $M_{\mathrm{dd}}$ の高い設計を目指し, 翼根部に使う翼型は 最大揚力係数 $C_{1 \text { max }}$ を重視して設計した . 以下に $\mathrm{AT} 1$ ブ レードの低騒音設計指針について，光の詳細を述べる．

2.1 HSI 騒音低減設計 HSI 騒音については 3 次元 の回転場非定常 Euler コードと波動方程式から導かれる Kirchhoff の式に基づく音響解析コードを組み合わせた方 法を用い, 上/下反角, 前進/後退角, テーパ比, 翼厚比と いった翼端形状の樣々なパラメータと HSI 騒音の因果関係 について調査を行った .これらの結果からは，上/下反角は HSI 騒音への影響が小さく，薄翼化や前進角，40 度以上の 後退角がHSI 騒音低減に特に効果的であるとの知見が得ら れた ${ }^{11)}$. また，これらの組み合せから，第 3 図に示される ような, 強い衝撃波が発生するスパン位置の前縁にデルタ 状の突起を配置し, 翼先端付近に大きな後退角を持たせた 形状は，特に衝撃波の抑制に効果的であり，ひいては光れ

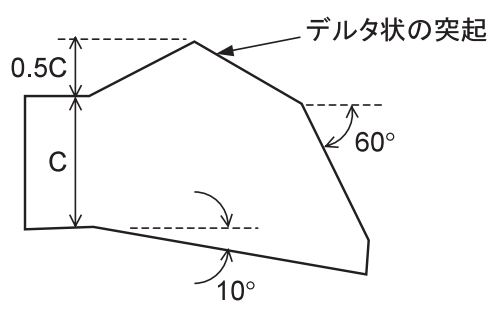

第 3 図 HSI 騒音低減の研究で得られた 3 重後退翼

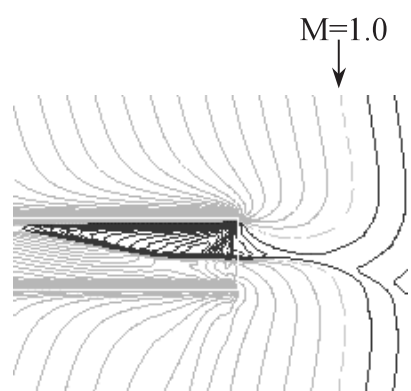

(a) 矩形ブレード
(b)AT1ブレード

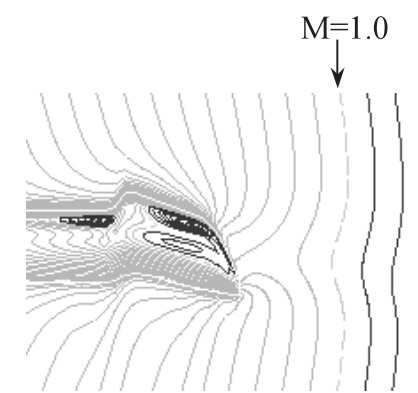

第 4 図 Euler コードにより解析した等マッハ数線図 (無揚力ホバリ ング, $\left.M_{\mathrm{tip}}=0.9\right)$

に近い形状を持つ BERP 翼も HSI 騒音低減効果が高いと の知見が解析により得られた ${ }^{12)}$. 従って, BERP 状の前縁 形状を採用することによって後退側の失速特性改善と HSI 騒音低減は両立できることがわかった．第 4 図は AT1 形状 のHSI騒音低減効果を確認するために Euler コードを用い， 翼端マッハ数が 0.9 の無揚力ホバリング状態での解析を行 い, 等マッ八数線图を矩形ブレードと比較した結果である 翼型はどちらも NACA23012 とした . 強い HSI 騒音が発 生しているかどうかは超音速領域の非局所化と呼ばれる現 象が発生しているかどうかから推測することができる. 非 局所化とはブレード座標系から見て翼面上の超音速領域が 翼外側の超音速領域とつながる現象のことを指す . 図中の 矩形については同現象か顕著に現れているのに対し，AT1 平面形ではこの非局所化が抑制されていることがわかる .

次に Kirchhoff 式に基づく音響解析コードを用い，面内 でロータ中心から半径の 3 倍離れた位置における無揚力ホ バリング時の音圧時刻歴波形を解析した結果を第 5 図に示 す . 本解析では翼型と平面形の効果を別々に確認するため, 翼型だけを NACA0008から新しく設計された AK080Aに 変えた場合 (Case 1), 翼型は同じ (NACA0012) で平面 形だけを矩形から AT1 平面形に変えた場合 (Case 2), 乥 して翼型と平面形の両方を変えた場合 (Case 3) の解析を 行った.HSI騷音の大きさは, 音圧波形の負のピーク値て評 価した . 図より翼厚比が同じであれば翼型か変わっても負 のピーク值はほとんど変わらないが (第 5 図 (a)), 平面形 状を変更することで負のピーク值は矩形ブレードの半分以 下に減少しており (第5 図 (b))，効果的にHSI騒音を低減 できていることがわかる.第 5 図 (c) より，総合的に新翼型 を適用した AT1 ブレードは, NACA23012mod 翼型を持 つ矩形ブレードに対し，HSI 騒音の低減に効果があること 

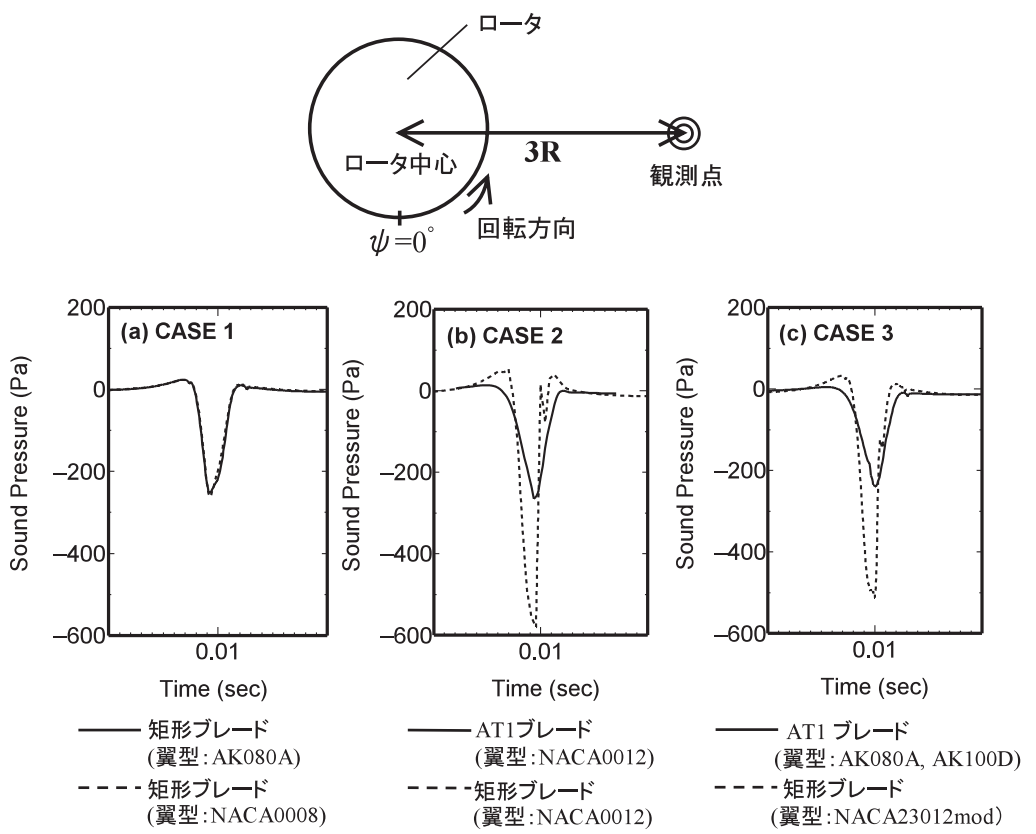

第 5 図 HSI 騒音の解析結果 (無揚力ホバリング条件, $M_{\mathrm{tip}}=0.9$ ，観測点：回転面内 $3.0 \mathrm{R}$ )

が確認できた .なお，NACA23012mod とはNACA23021 に後縁タブを付加した翼型で, BK117ヘリコプタにも採用 されていることから，今回基準として用いた .

2.2 BVI 騒音低減設計 翼端形状が BVI 騒音に及ぼ す影響については, ATIC と NAL が共同で開発してきた 解析手法を用いて調べた .この手法は CAMRAD II と呼ば れる揚力線理論と自由渦理論に基づくヘリコプタ総合解析 ツールを用いて複雑な翼端渦軌跡を含むロータのトリムを 求め, ブレード周りの流机場は Euler コード，遠方へ伝播 する騒音は Ffowcs-Williams and Hawkings (FW-H) の 式に基づく音響解析コードを使って解析する．この手法を 組み合わせ騒音解析法と呼ぶ”13,14) .

一般に BVI 騒音を低減する方法として，(1)干渉時のブ レードと渦の垂直距離を広げる, (2)ブレードと翼端渦の交 差角を大きくする，(3)翼端渦の強度を弱める，の 3 つが有 効であると言われている .これを翼端形状の改良により実 現しようとした場合，例えばブレード/渦間距離を広げるに は翼端に上/下反角をつける, 交差角を大きくするには翼端 に前進/後退角をつける, 翼端渦を弱めるにはテーパをつけ る，といった方法が考えられる。例えば先に延べたVANE 翼や OGEE 翼は翼端渦の強度を弱める効果を狙ったもの である.第 6 図は緩降下飛行条件（前進速度 $V=50 \mathrm{kt，}$ ティップ・パス・プレーン角 $\left.\alpha_{\mathrm{TPP}}=2^{\circ}\right)$ において, 翼端 形状を樣々に変えた時にBVI騒音の音圧波形がどのように 変化するか, 解析により調べた結果を示す．解析モデルは 回転半径 $0.958 \mathrm{~m}$ の 2 枚ブレード・モデル・ロータで, 矩 形をべースに翼端部 $90 \%$ 位置に 40 度の前進/後退角， 20 度の上/下反角， $1 / 3$ テーパをつけた場合の計 6 ケースに ついて比較した .この条件では矩形に対して下反角, 前進 角, テーパの付加か騷音低隇に有効であることがわかった . この内, 下反角による騒音低減効果は, 干渉時のブレード/
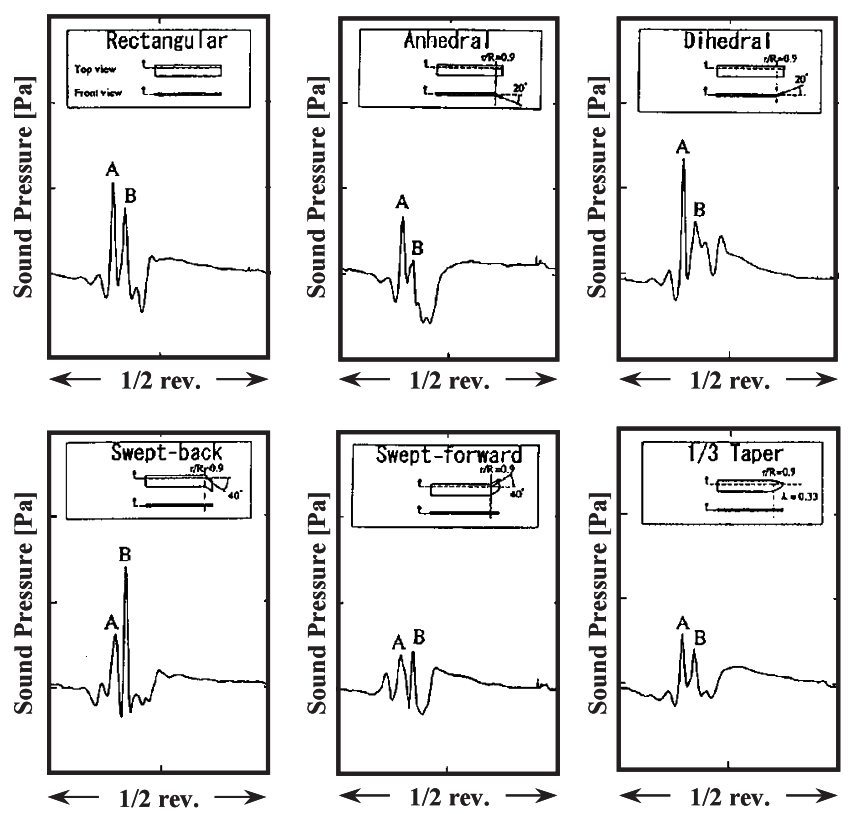

第 6 図＼cjkstart翼端形状の違いによる BVI 騒音への影響 $(V=50 \mathrm{kt，}$ $\left.C_{\mathrm{T}}=0.0054, \alpha_{\mathrm{TPP}}=2 \operatorname{deg} \mathrm{AFT}\right)$

渦間距離が広がつたためであるが，逆にこれまでBVI騒音 が発生していなかった条件でブレード/渦間距離が縮まって BVI騒音がうるさくなる可能性があり, 飛行条件によって は逆効果となりうる．弚こでブレードと渦の衝突を避ける よりは衝突が起きても大きな音が発生しないような改良の 方か実用的であると考え，新ブレードには下反角をつけず， 前進角やテーパの付加による BVI騒音低減効果を取り入れ るようにした . 単なる前進角の付加は頭上げモーメントを 増大させるため, 結果的に BERP 翼のように前縁を一旦前 進させ端部で後退させてピッチング・モーメントを増大さ せない形状が, 性能へのインパクトを抑えて平行 BVI を避 

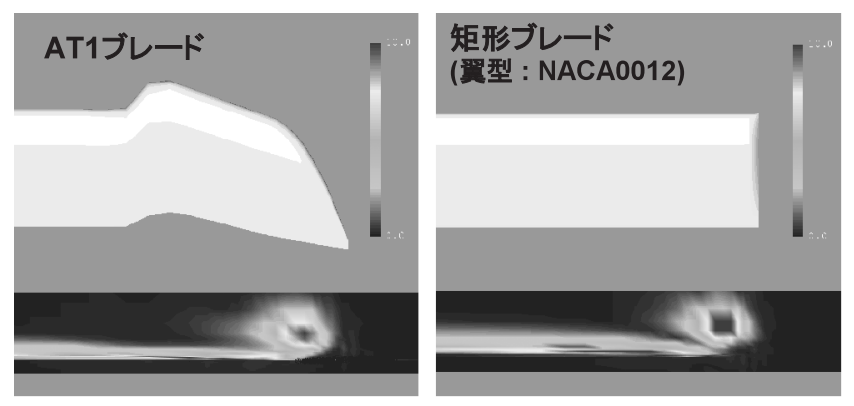

第 7 図 翼後方から見た翼端渦の等渦度分布 (ホバリング条件,$M_{\mathrm{tip}}=$ $0.4)$

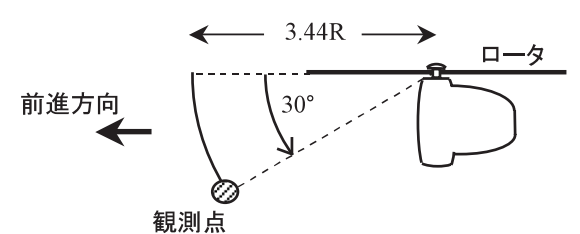

※OA: Over All Sound Pressure Level [dB(A)]

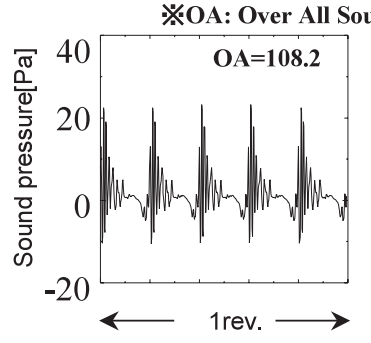

(a)矩形

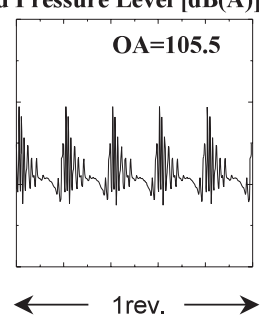

(b)AT1
第 8 図 BVI 騒音の解析結果 $\left(V=50 \mathrm{kt}, C_{\mathrm{T}}=0.0064, \alpha_{\mathrm{TPP}}=\right.$ $2 \operatorname{deg} \mathrm{AFT}$ )

けるために適していると考えた．また，端部が強いテーパ となっているため翼端渦の強さを弱める効果も期待できる . これらの効果を解析により確認し, 設計へ反映させていっ た . 第 7 図は AT1 ブレードの翼端渦の渦度分布を 3 次元の 定常 Navier-Stokes コードで解析し，矩形ブレードの关れ と比較したものである . 両者は発生する推力が同じになる ようにピッチ角を変えており，第 7 图から AT1 ブレードの 翼端渦が矩形ブレードの兰れよりも中心部の渦度が弱まっ ていることがわかる.AT1 をロータに適用した際のBVI 騒音低減効果については前述した組み合わせ騒音解析法を 用いて予測した . 第 8 図は, AT1 ブレードと矩形ブレード のBVI騒音の音圧波形を解析した結果を示す . 解析モデル は回転半径 $2 \mathrm{~m}$ の 5 枚ブレード・モデル・ロータで, 解析 条件は第 6 図の検討を行った時と同じ緩降下飛行条件 $(V$ $\left.=50 \mathrm{kt}, \alpha_{\mathrm{TPP}}=2^{\circ}\right)$ とした。観測点は一般に BVI 騒音 が強く伝播すると言われるロータ面から 30 度斜め下方前 方で, ロータ中心からの距離が回転半径の 3.44 倍の位置に とった . 第 8 図よりAT1 ブレードは矩形ブレードに対し， オーバー・オール $(\mathrm{OA})$ 值にして約 $3 \mathrm{~dB}$ 弱 BVI 騷音が 低減しており，AT1 ブレードが BVI 騒音低減にも効果が あることか確認できた 。

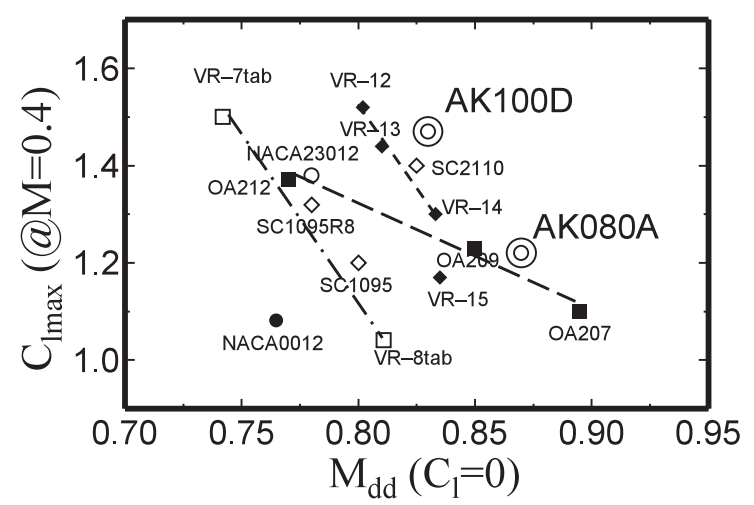

第9図 AT1 ブレード用新翼型の性能

2.3 失速特性改善 最後に性能面におけるブレード設 計について述べる、特に ATICではロータ騒音を低減する ために回転数低下や薄翼化といった方法を採用しているた め，ブレード形状を低騒音化だけで決めてしまうと，ロー 夕後退側の翼端失速を悪化させ振動増大につながる恐れが ある.従って，新ブレードは，低騷音化を実現するととも に翼端部の失速特性を改善し，現有機並の性能を維持でき るように設計することが重要である，乥こで，低回転数下 での薄翼化を実現するため, 2 次元最大揚力係数 $C_{1 \text { max }}$ が 高く, 抵抗発散マッ八数 $M_{\mathrm{dd}}$ の低い高性能翼型の開発と, BERP 形状を参考にして翼端が高迎角になった時の失速を 遅らせる平面形状の研究を進めた .

新翼型の設計は主に 2 次元 Euler および Navier-Stokes コードを用いて行った . 新ブレードには翼端部用に翼厚比 $8 \%$ の AK080A，翼根用に翼厚比 $10 \%$ の AK100D を適用 することにした．AK080A は高速飛行性能や HSI 騷音低 減効果を考えて $M_{\mathrm{dd}}$ 向上を優先して設計された．逆に， $\mathrm{AK} 100 \mathrm{D}$ は低速域での性能を重視し， $C_{1 \text { max }}$ 向上を優先し て設計されている.設計後, 航技研の 2 次元遷音速風洞にお いて , 2 つの翼型の性能を確認したところ , 両翼型の $M_{\mathrm{dd}}$ および $C_{1 \text { max }}$ は第 9 图に示す通り，欧米諸国の翼型と比較 しても高いレベルの性能を有することが確認された ${ }^{15)}$.

一方で平面形状の研究については, 固定翼模型による低 速風洞試験を主体にして進めた . 試験は日本飛行機の $2 \mathrm{~m} \phi$ 低速風洞で行った . 第 10 図に風洞試験の概要図を示す.供 試体は BERP 形状をベースに翼根部，中間部及び先端部の 3 つのセグメントに分かれた組みかえ方式になっており，こ れにより前縁の張り出し量や先端部の前縁形状などのパラ メータを変えて試験を行うことが可能である，供試体の基 本寸法は翼根部の翼弦長が $240 \mathrm{~mm}$, スパン長が $600 \mathrm{~mm}$ で, 翼型は根元でNACA23012 とし, 先端へ向かう途中で 翼弦長が変わる場合は絶対厚みが一定となるよう翼厚比を 変えた. 試験では供試体根元の 3 分力を測定して失速角や 3 次元最大揚力係数 $C_{\mathrm{L} \text { max }}$ を比較するとともに，失速角付 近で翼面上の流机場を気流系により可視化し，剝離の樣子 を調べた。

第 11 图および第 12 図は風試結果の一例を示す. 第 11 図は前縁のキンク部分や後退角の部分を直線的あるいは曲 


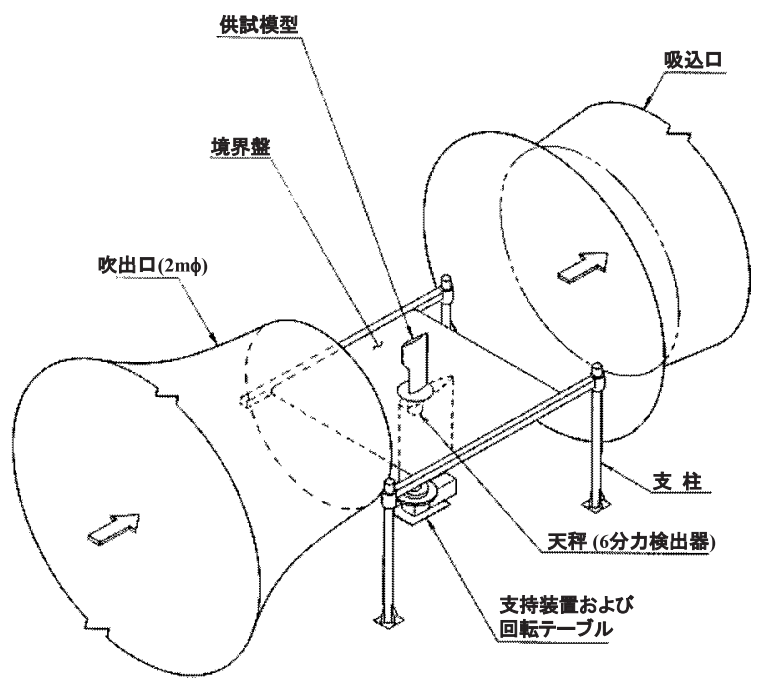

第 10 図＼cjkstart翼端形状モデルの風洞試験概要図
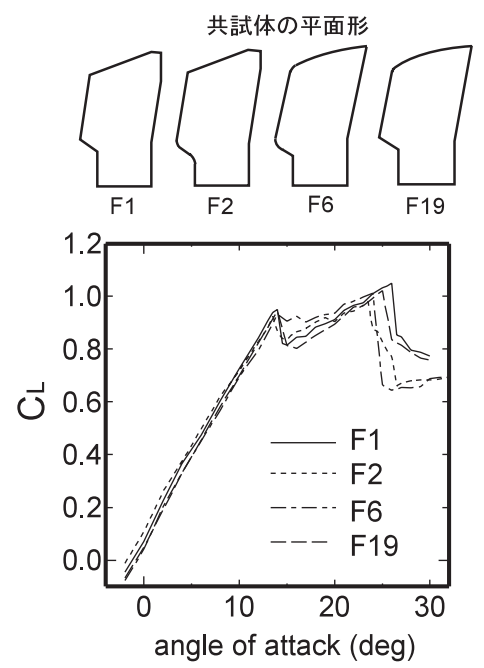

第 11 図 前縁形状の違いが失速特性に及ぼす影響 $(M=0.1)$

線的な形状に変えた場合の， $C_{\mathrm{L}}-\alpha$ (揚力係数-迎角) カー ブへの影響を示している.図では F6 以外の形状は迎角 14 度付近で一度 $C_{\mathrm{L}}$ が急落し，乥こからまた緩やかに $C_{\mathrm{L}}$ が 上昇するが， $C_{\mathrm{L}}$ の急落はロータ振動を増大する原因とな るため好ましくない . $C_{\mathrm{L}}$ の急落は張り出し部より内側の 翼根部が一気に剝離するために生ずるが, 張り出し部から 発生する渦か張り出し部外側の領域での剝離を抑制するた め迎角 20 度付近まで $C_{\mathrm{L}}$ は増加する .この時，F6のよう にキンク部分を曲線状に滑らかにした方が翼根部失速後の $C_{\mathrm{L}}$ が高く急変動が起こらないので, ロータ性能にとって好 ましいことがわかった .

次に第 11 図中で最も揚力係数の急変動が小さかった F6 をベースに中間部のスパン長を伸ばし，さらに後縁を前縁 にトレースするように凹ませた場合の空力特性への影響を 第 12 図に示す . 同図より，J2 は良好な失速特性を維持し たまま，迎角変動に対するピッチング・モーメントの変化 が最も小さかったことから, 新ブレードの平面形のベース に J2 を採用した . 最終的に後縁の窪みをやや小さくし，新

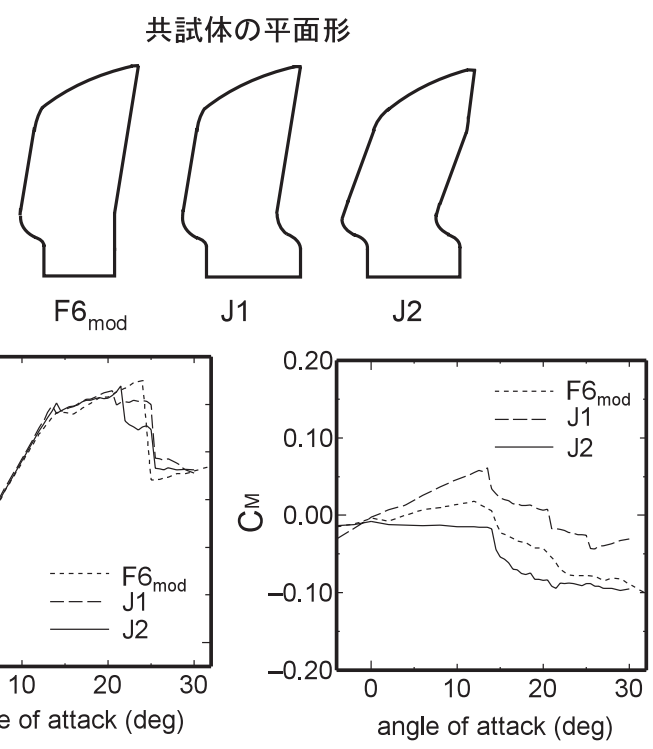

第 12 図 後縁形状の違いが失速特性およびモーメントに及ぼす影響 $(M=0.1)$

翼型と組み合わせて AT1 ブレードの形状を決定した . AT1 形状の失速特性を川崎重工業 (株) の遷音速風洞で確認し たところ，第 13 図に示すように矩形に比べモーメントが やや大きいものの, 失速角および $C_{\mathrm{L} \text { max }}$ が伸びており，良 好な失速特性を有していることが確認された。

以上のようにAT1 ブレードの前縁張り出しと端部での大 きな後退角は 2 つの衝撃騷音の低減に有効であることを確 認した . また, 弚の張り出し量や後退角の大きさなど細か な形状については失速特性への影響が大きかったため，性 能面を重視して決めた . また, 翼型については AK100D と

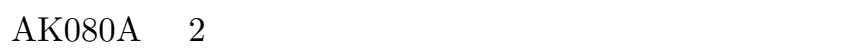
と翼端部に配置した。产の結果, AT1 ブレードは騒音/性 能の両方で矩形ブレードを上回るとの見通しを得た .

\section{3. モデル・ロータ風試結果}

新ブレードを用いた低騷音ロータの騒音およひ性能を評価 するため, オランダにある世界最大の低騒音風洞 DNW に おいて回転半径 $2 \mathrm{~m}$ のモデル・ロータによる風洞試験を行っ た . モデル・ロータの諸元を第 1 表に示す. 供試体ブレード は, 翼端が第 14 図に示す矩形 , BERP 模擬およびAT1の 3 種類を製作した . 翼型は矩形ブレードがNACA23012mod で残りの 2 体は新翼型である $\mathrm{AK} 100 \mathrm{D}$ と AK080A を適用 した . 各ブレードのねじり下げ, 翼弦長, 翼厚比は第 15 図 に示す分布を持つ。

まず始めに HSI 騒音の低減効果について結果を示す．風 試では HSI 騒音の評価ができる位置にマイクか設置されて いないが, 衝撃波の強さと HSI 騒音の大きさは極めて相関 が良いことから，衝撃波の強さでHSI騒音の評価を行った。

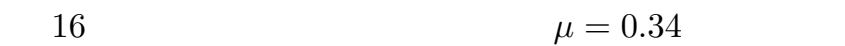
ロータ前進側の翼端部圧力分布について解析と実験の比較 を示す . 同図から AT1 ブレードでは矩形ブレードよりも圧 力変動が緩やかで衝撃波か弱められていることが解析と実 


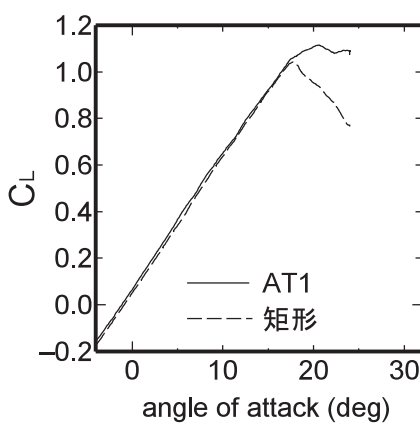

(a) $\mathrm{C}_{\mathrm{L}}-\alpha$ curves

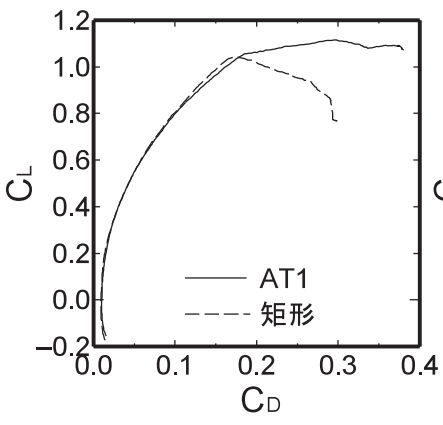

(b) $\mathrm{C}_{\mathrm{L}}-\mathrm{C}_{\mathrm{D}}$ curves

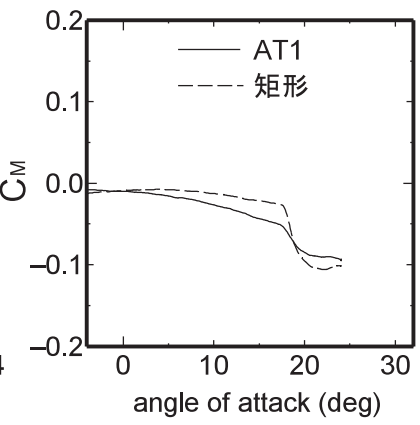

(c) $\mathrm{C}_{\mathrm{M}^{-}} \alpha$ curves

第 13 図 遷音速風洞における AT1 翼端の空力特性の計測結果 $(M=0.4)$

\begin{tabular}{ll} 
第 1 表 $1 / 3$ スケール・モデル・ロータの諸元 \\
\hline 回転半径 & $2.0 \mathrm{~m}$ \\
ブレード枚数 & 5 \\
翼弦長 (翼根部) & $0.1107 \mathrm{~m}$ \\
翼端速度@100\% RPM & $210 \mathrm{~m} / \mathrm{s}$ \\
ねじり下げ (矩形ブレード) & $-8^{\circ} \mathrm{liner}$ \\
\hline
\end{tabular}

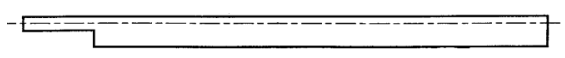

(a) 矩形ブレード

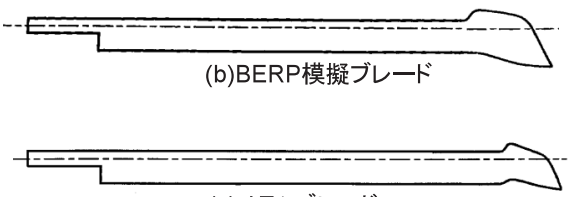

(c) AT1 ブレード

第 14 図 モデル・ロータ風試における供試体ブレード外形

験の両方の結果から見てとれる .これにより AT1 ブレード がHSI 騷音の低減に効果的であることが示された . 同時に Euler/Kirchihoff コードを用いた HSI 騒音解析がブレード 設計に有用であることが示された 。

BVI騒音の評価は同騒音が発生しやすい緩降下飛行条件
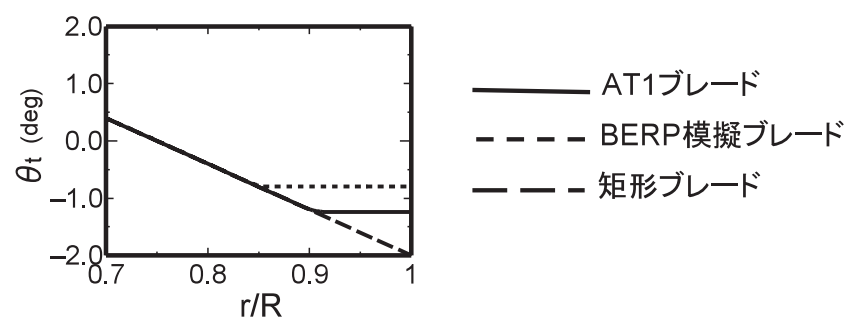

(a) ねじり下げ分布

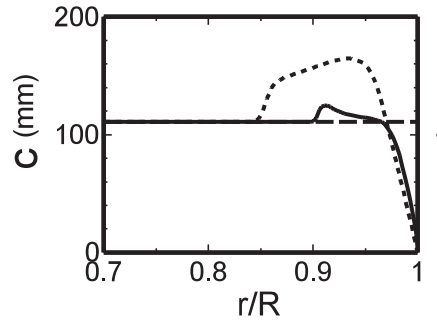

(b)翼弦長分布

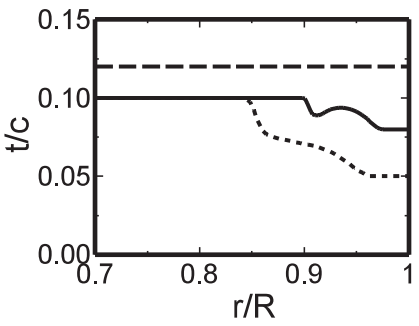

(c) 翼厚比分布
第 15 図 供試体ブレードの諸元比較

において，ロータ面下方の等騷音レベル分布を用いて行っ た . 計測面を第 17 図に示す.等騷音レベル分布は 13 本の マイクロフォン列を主流方向に $0.45 \mathrm{~m}$ 間隔でトラバース

CFD解析 —— 計測值 $\left\{\begin{array}{l}0 \text { :翼上面 } \\ 0 \text { :翼下面 }\end{array}\right.$
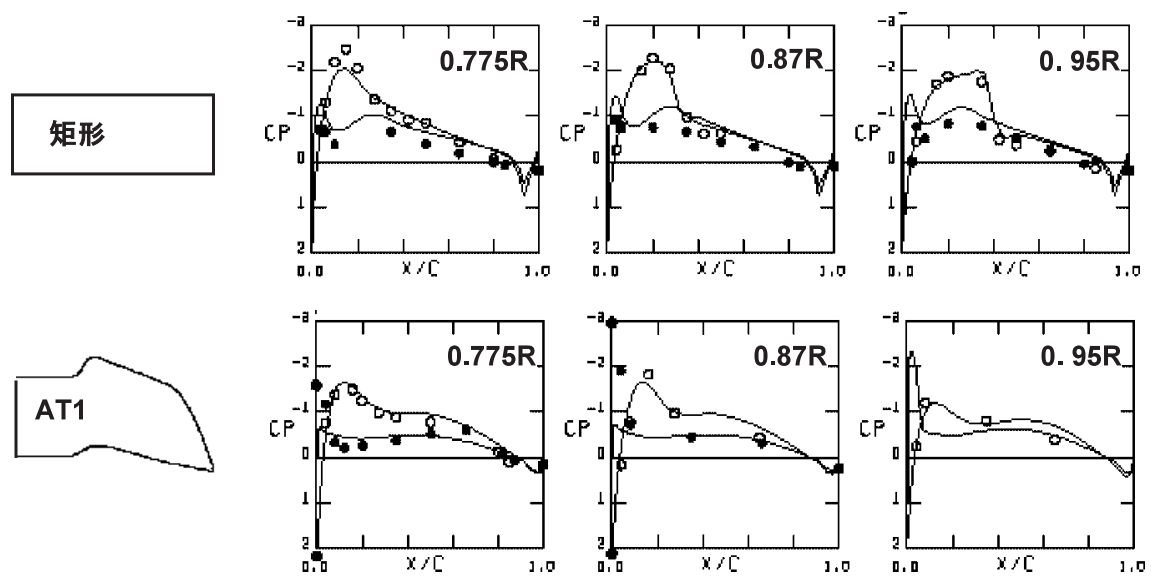

第 16 図 高速前進飛行時におけるブレード翼端部の圧力分布 $\left(C_{\mathrm{T}}=0.0064, M_{\mathrm{tip}}=0.604, \mu=0.34\right)$ 
低騒音ヘリコプタ・ブレードの開発と炎の実証について (近藤・辻内・村重・西村・青木 ·土橋・山川・青山・齊藤 $) \quad 15$

させ計測しており，オーバーオール值は BVI騒音が支配的 な周波数帯域である 355 ～ $5630 \mathrm{~Hz}$ の範囲で算出した . 計 測結果を第 18 図に示す. 同図より BVI 騷音が最も顕著で あった条件 $\left(\mu=0.16, \alpha_{\mathrm{TPP}}=4.72^{\circ}\right)$ において, $\mathrm{AT} 1$ ブレードはロータ前進側中部に確認できる騒音の最大值を $1 \sim 2 \mathrm{~dB}$ 程度低減し, また同分布図の前方エリアでは, 矩 形との差が $5 \sim 7 \mathrm{~dB}$ と効果的に騒音が低減されていること がわかる. 前進率 $\mu$ を変えずにロータ迎角 $\alpha_{\mathrm{TPP}}$ を変化 させても定性的な傾向は変わらないことも確認された .

一方，ロータ性能であるが，第 19 図に示すように全飛 行速度域で, 実験を行った 3 種類のブレードの内, AT1 ブ レードの必要パワーが最も小さく性能が良かった．しかし， 高速巡航時 $(\mu=0.32)$ においては, 第 20 図に示すよう にロータ推力が大きくなるに従い AT1 ブレードの性能の 優位性が見られなくなってくることがわかる .これは AT1 が予想よりも早く翼端失速を起こしているためと考えられ る.これらの結果を補足する図を第 21 図に示す.第 21 図 (a) はホバリング時におけるブレード・スパン方向の $C_{1}$ 分 布を示す . ロータ推力が $2 \mathrm{G}$ になると翼端部の $C_{1}$ が翼型の $C_{1 \max }$ よりも大きくなっていることがわかる . 第 21 図 (b)

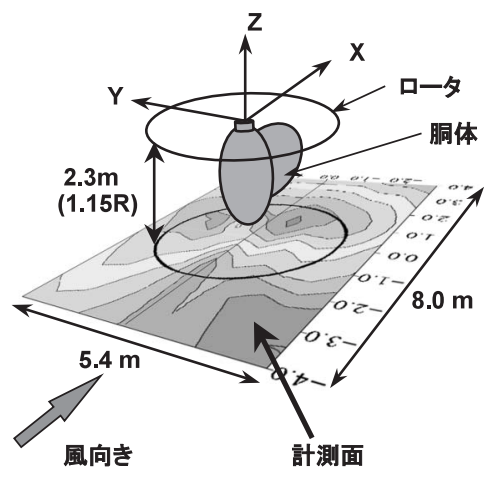

第 17 図 トラヴァース・マイクによる等騒音レベル分布の計測面
は前進飛行時における $95 \%$ 半径位置の $C_{1}$ の局所マッハ数 に対する変化を示している. 同図からロータ推力が $1.5 \mathrm{G}$

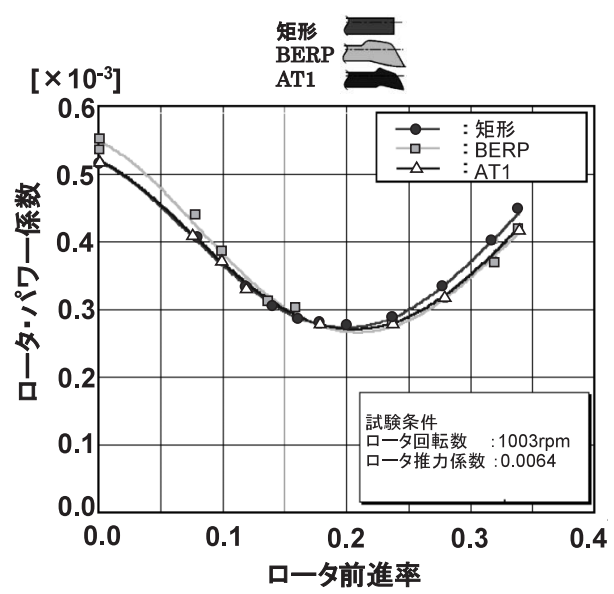

第 19 図 $1 \mathrm{G}$ 前進飛行時のロータ性能比較

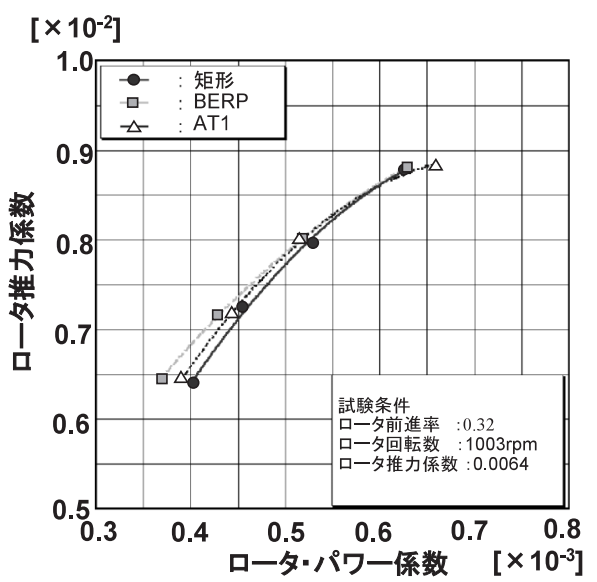

第 20 図 高速巡航時のロータ性能比較

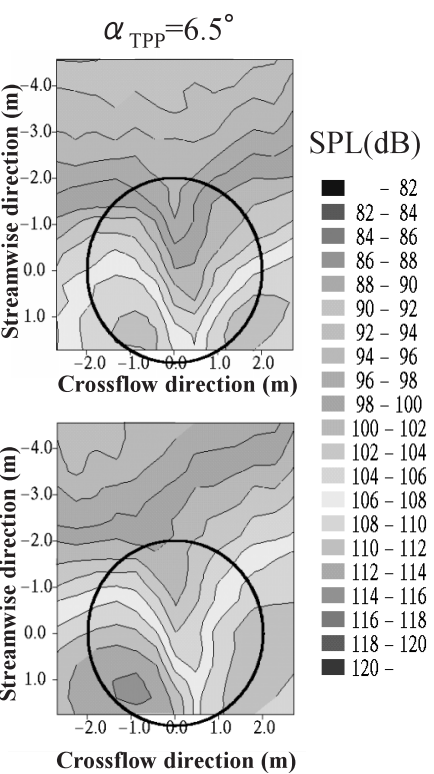

第18 図 BVI 騷音発生条件における等騷音レベル分布の計測結果 


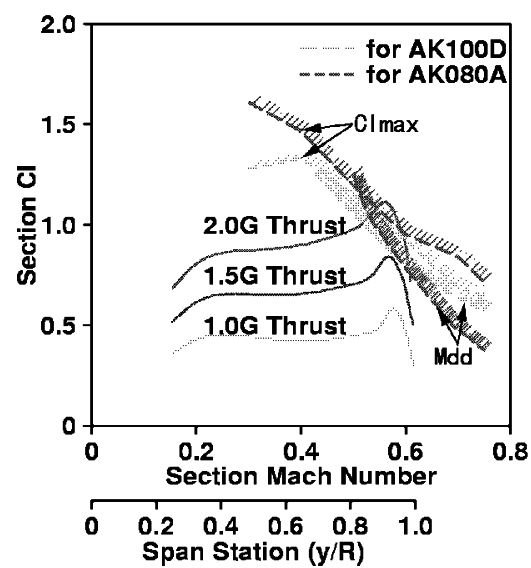

(a) ホバリング

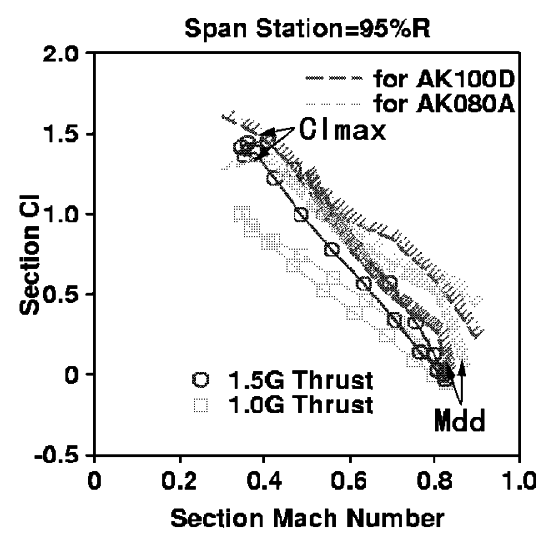

(b) 高速巡航 $(\mu=0.4)$

第 21 図翼型性能に対するブレード作動領域

の場合 , 低マッハ数領域では翼端部の局所 $C_{1}$ が翼端に使わ れている $\mathrm{AK} 080 \mathrm{~A}$ 翼型の $C_{1 \max }$ よりも大きくなっている ことがわかる.

AT1 ブレードの失速特性が高推力時に悪くなる原因とし ては(1)翼端部のねじり下げをなくしたため, 高推力時に翼端 のピッチ角が大きくなりすぎた，(2) AK100D から AK080A への遷移区間の設計が十分でなかった，等か学げられる.従っ て今後はねじり下げ分布や翼型の配置を最適化することで， ロータ性能を向上させる余地は十分にあると考えられる .

\section{4. ま と め}

騒音解析と低速風洞試験をパラメトリックに行いながら， 低騒音かつ高性能なブレード形状について研究を進めた結 果の集大成として，AT1 ブレードを新たに設計した。炎の 形状が狙った効果をまとめると次の通りである .

・翼端部での薄翼化と前緣部の張り出しにより, 衝撃波を 効果的に抑制し, HSI 騒音を低減する。

・前縁張り出しと強いテーパの組み合わせにより BVI騒音 を低減する。

・前縁張り出しから発生する渦の効果で失速角を延ばし， 薄翼化, 低回転数等によるロータ性能低下を防ぐ。

最終的にモデル・ロータ風洞試験により，少の騒音およ び性能を確認したところ，騒音については予想した低減効 果が見られ，かつ前進飛行中のロータ性能も良好であった . ただし , 高推力時におけるロータ性能は予想よりも悪く，ね じり下げや翼型配置といった 3 次元翼としての設計を最適 化することが今後の課題として残された．これにはロータ CFD コード16) を積極的に利用することを考えている．今 後はより実用化を目指した研究を進めていく予定である.

\section{参 考 文 献}

1) 山川榮一, 齊藤 茂 : 講義ヘリコプタ工学の基礎と応用一第 6 回ヘリコプタの騒音一, 日本航空宇宙学会誌, 48 (2000), pp. 280-288.

2) Yu, Y. H.: Rotor Blade-Vortex Interaction Noise, Prog. Aerospace Sci. Int. Rev. J., 36 (2000), pp. 97-115.
3) Philippe, J. J. and Vuillet, A.: Aerodynamic Design of Advanced Rotors with New Tip Shapes, 39th Annual Forum of the American Helicopter Society, St. Louis, Missouri, 1983.

4) Marze, H. J. and Philippe, J. J.: A Quiet Helicopter-A Research Programme Today-A Reality Tomorrow, 20th European Rotorcraft Forum, 1994.

5) Perry, F. J.: Aerodynamics of the Helicopter World Speed Record, 43th Annual Forum of the American Helicopter Society, 1987.

6) Scott, M., Sigl, D. and Strawn, R.: Computational and Experimental Evaluation of Helicopter Rotor Tips for High Speed Forward Flight, AIAA Paper 89-1845, 1989.

7) Beddoes, T. S. and Pike, A. C.: Noise Reduction with a Twin Tip Vortex Configuration, 52nd Annual Forum of the American Helicopter Society, 1996.

8) Boxwell, D. A. and Schmitz, F. H.: Full-Scale Measurements of Blade-Vortex Interaction Noise, 36th Annual Forum of the American Helicopter Society, 1980.

9) Wagner, W. J.: Comparative Measurements of the Unsteady Pressures and the Tip-Vortex Parameter on Four Oscillating Wing Tip Models, 10th European Rotorcraft Forum, No. 9, 1984.

10) Kobiki, N., Murashige, A., Tsuchihashi, A., Hasegawa, Y., Kondo, N., Nishimura, H., Tsujiuchi, T., Inagaki, K. and Yamakawa, E.: Correlation between Analysis and Wind Tunnel Test Results-What ATIC Has Done so Far-, 55th Annual Forum, American Helicopter Society, Montreal, Canada, 1999.

11) Aoyama, T., Aoki, M., Kondo, N., Saito, S. and Kawachi, K.: Effect of Blade-Tip Shape on High-Speed Rotor Noise, AIAA Paper 96-2380, 1996.

12) Aoyama, T., Kawachi, K. and Saito, S.: Effect of Blade-Tip Planform on Shock Wave of Advancing Helicopter Blade, J. Aircraft, 32, 5 (1995), pp. 955-961.

13) Aoyama, T., Kondo, N., Aoki, M., Nakamura, H. and Saito, S.: Calculation of Rotor Blade-Vortex Interaction Noise Using Parallel Super Computer, 22nd European Rotorcraft Forum, No. 8, 1996.

14) Nakamura, H., Nishimura, H., Kondo, N., Yamakawa, E., Aoyama, T. and Saito, S.: Effect of Blade Geometry on BVI Noise in Various Flight Conditions, Heli Japan 98, 1998.

15) 青木 誠, 小曳昇, 山川榮一, 齊藤 茂, 重見仁, 佐藤 衛, 神田 宏: 高性能/低騒音ヘリコプタ・ブレード用翼型の研究一 遷音速二次元風洞試験一, NAL-TM-730，1998.

16) Kondo, N., Ochi, A., Nakamura, H., Aoyama, T., Saito, S. and Yamakawa, E.: Validation of Rotor Aerodynamic and Acoustic Prediction Methods Using ATIC 2nd Model Rotor 26th European Rotorcraft Forum, No. 102, 2000. 